\title{
Transgressing the Division of Powers: The Case of the James Bay and Northern Quebec Agreement
}

\author{
Christa Scholtz ${ }^{(D)}$ and Maryna Polataiko
}

\begin{abstract}
In 1975, the Bourassa government received legal advice that the James Bay Northern Quebec Agreement exceeded provincial jurisdiction. Legal counsel advised the constitutionality of the Agreement be secured through formal constitutional amendment. No such amendment was sought. Based on authorized access to Premier Bourassa's archived dossier on the Agreement's negotiation, this article sets out the following: 1) why the provincial government sought to encroach on federal jurisdiction; 2) the strategic means employed to insulate the Agreement from s. 91(24) litigation; and 3) provincial negotiators' views on how judges would approach the Agreement going forward. This article confirms theoretical expectations about when governments might coordinate to transgress federalism's division of powers: a high probability that courts would find a transgression occurred, and a high political cost should governments not coordinate on a transgression strategy.
\end{abstract}

Keywords: federalism, James Bay and Northern Quebec Agreement, constitutional law, division of powers, judicial politics, bargaining

\section{Résumé}

En 1975, le gouvernement de Robert Bourassa a reçu un avis juridique qui stipulait que la Convention de la baie James et du Nord québécois transcendait les compétences provinciales. Le conseiller juridique a donc recommandé de garantir la constitutionnalité de cette Convention au moyen d'un amendement constitutionnel formel. Aucun amendement de ce type n'a toutefois été demandé. En se basant sur les dossiers archivés du premier ministre Bourassa relatifs à la négociation de la Convention, et qui furent l'objet d'un accès autorisé, cet article traite des points qui suivent : 1) le contexte politique dans lequel la province a utilisé cette Convention pour empiéter sur les compétences fédérales; 2) les moyens stratégiques utilisés pour mettre la Convention à l'abri des litiges en vertu du paragraphe 91(24); et 3) les points de vue des négociateurs provinciaux sur la manière dont les juges aborderont la Convention dans le futur. Cet article confirme les conditions théoriques qui pourraient permettre aux gouvernements

Canadian Journal of Law and Society / Revue Canadienne Droit et Société, 2019. This is an Open Access article, distributed under the terms of the Creative Commons AttributionNonCommercial-NoDerivatives licence (http://creativecommons.org/licenses/by-nc-nd/4.0/), which permits non-commercial re-use, distribution, and reproduction in any medium, provided the original work is unaltered and is properly cited. The written permission of Cambridge University Press must be obtained for commercial re-use or in order to create a derivative work.

Volume 34, no. 3, pp. 393-415. doi:10.1017/cls.2019.35 
de se coordonner afin de transgresser le partage des pouvoirs relatif au fédéralisme canadien, soit une forte probabilité qu'une transgression soit constatée par les tribunaux et la présence d'un coût politique élevé si les gouvernements ne se coordonnent pas sur une stratégie de transgression.

Mots clés : fédéralisme, Convention de la Baie-James et du Nord québécois, droit constitutionnel, partage des pouvoirs, politique judiciaire, négociation

These claims cannot be settled by the courts...All that courts can do is enforce certain rights along the way... but the courts cannot settle the claims. ${ }^{1}$

[Des légalistes] trouvaient toujours quinze raisons pourquoi je ne pouvais pas faire telle chose. Les avocats nétaient pas innovateurs. ${ }^{2}$

\section{Introduction ${ }^{3}$}

Signed in 1975, the James Bay and Northern Québec Agreement (hereafter JBNQA, or the Agreement) is the first Indigenous treaty settlement of Canada's modern land claims era. Aboriginal and treaty rights were subsequently constitutionalized in 1982, with modern land claim agreements explicitly protected in 1983. Three decades later, the Supreme Court of Canada (SCC) called the JBNQA “an epic achievement in the ongoing effort to reconcile the rights and interests of Aboriginal peoples and those of non-Aboriginal peoples in Northern Québec." Indeed, the Agreement enjoys supra-legislative status in the Canadian hierarchy of legal norms. ${ }^{5}$ Today, the constitutionality of the JBNQA is at the very least presumed; mostly, it is unquestioned. This was not always so. This paper goes back to the JBNQA's beginnings, establishing that, in 1975, its drafters faced a very different legal assessment of its future constitutionality. Confidential legal advice held that the Agreement as then drafted certainly transgressed exclusive federal legislative authority over "Indians and lands reserved for the Indians." Despite this legal advice, the Québec government (and its negotiating partners) chose to enact the Agreement. Why did they proceed with the Agreement? How did provincial negotiators understand and weigh their policy options, given the political and judicial risks they faced?

Drawing on Premier Robert Bourassa's archived dossier of the JBNQA negotiations, we show that internal and external legal counsel repeatedly advised that the constitutionality of the JBNQA as then negotiated could only be satisfactorily addressed

1 John Ciaccia, “The Settlement of Native Claims," Alberta Law Review 15 (1973): 556. From November 1973 until the JBNQA's ratification, John Ciaccia was Premier Robert Bourassa's chief negotiator.

2 "[Jurists] always found fifteen reasons why I couldn't do something. The lawyers were not innovators.” Transcript of interview with John Ciaccia, Montréal, Bibliothèque et Archives nationales du Québec (Centre d'archives de Montréal, fonds Roger Lacasse, dossier 1990-11-069). Please note that the English translations provided in this paper of the original French texts will hold to the terminology used in the original sources.

3 This research was supported by the Social Sciences and Humanities Research Council of Canada (Insight Grant program).

4 Québec (Attorney General) v Moses 2010 SCC 17, [2010] 1 SCR 557 at para 14 [Moses].

5 Binnie J, for the majority in Moses, implicitly makes this point at para 10, while LeBel and Deschamps JJ, for the minority (dissenting on other grounds), explicitly do so at para 92.

6 British North America Act, 1867 (UK), 30 \& 31 Victoria, c 3, s 91(24). 
through a formal amendment to the British North America Act, 1867 (BNA Act). In response, provincial negotiators did not push their federal counterparts to set the formal constitutional amendment process into motion. Rather, they adopted a twopronged approach. First, they included a clause intended to dissuade likely litigants from pursuing this jurisdictional question in the courts. Second, in whatever time this clause bought the Agreement signatories, provincial negotiators sought to build public and media support for the Agreement. The province's negotiators argued for technical modifications to the project precisely because such changes would, they posited, sway public and press opinion in favour of the Agreement, with the courts following suit. ${ }^{7}$ The province's negotiators believed that future courts, as rational strategic actors, would not invalidate a treaty with long-term support from both the larger public and its Indigenous signatories. In other words, Robert Bourassa's negotiators understood the JBNQA's future to rest on its political, rather than legal, foundations.

This concrete case of political bargaining should be of interest to scholars of judicial politics in political science, history, law, and elsewhere. The fact that the provincial negotiators of the JBNQA undertook what they were advised was a clear transgression of the constitutional division of powers lends empirical support to predictions generated in the recent game theoretic literature on federalism enforcement. Specifically, the JBNQA falls in line with predictions from a safeguard theory of federalism. Jenna Bednar's theoretical framework sets out why transgression is more rational than full compliance. ${ }^{8}$ However, the saga of the negotiation of the JBNQA pushes further than Bednar's influential model. The JBNQA is an important case where provincial and federal governments were able to coordinate on a cooperative transgression strategy under a crucial and counterintuitive presumption: a perceived certainty in the short term that the courts would strike down the transgression if given the chance. This confirms a strategic logic explored in other formal theory work on the limited effectiveness of a judicial safeguard in preventing such transgressions. ${ }^{9}$ This empirical case also pushes beyond what the formal theoretical work in federalism enforcement has focused on so far. In 1975, provincial negotiators were operating under a shared belief that courts would invalidate legislation in the short term, but given a successful long-term political strategy, the threat of judicial invalidation was believed to decrease significantly.

We proceed as follows. Part 2 canvasses the theoretical literature in political science, setting out the conditions under which we would expect governments to transgress the division of powers. A key point from the literature is that transgressions can be rational despite a very high probability of a judicial veto. Parts 3 and 4 move into the empirical case, setting out the historical context of the Agreement. The historical sections illustrate Québec's changing preferences regarding the division of powers. Québec preferred to support the federal jurisdiction over "Indians

Memo to Robert Bourassa titled "James Bay Project and Native Claims" (3 January 1974), Montreal, Bibliothèque et Archives nationales du Québec, fonds Robert Bourassa, P705, 1987, 1987-07-001/166, dossier 6.

8 Jenna Bednar, The Robust Federation: Principles of design (New York: Cambridge University Press, 2009).

9 See Gemma Sala, "Can Courts Make Federalism Work? A Game Theory Approach to CourtInduced Compliance and Defection in Federal Systems," Economies 2 (2014): 193. 
and lands reserved for the Indians" until the 1970s, but shifted its preference to challenging that division of powers after 1970. To support these claims, we establish the conditions under which territories were transferred to Québec, and the interest the province had in those territories prior to the negotiation of the JBNQA.

We show how the Quiet Revolution led the Lesage government to seek administrative delegation from the federal government over Inuit affairs, and then how the Dorion Commission deemed administrative delegation an insufficient response to what the Commission considered the province's proper role in Nouveau Québec. ${ }^{10}$ This establishes the immediate political context for why the Bourassa government saw the JBNQA as not only a bargain with the Cree and Inuit, but also as a means to decrease the federal government's legislative jurisdiction in the James Bay territory. This historical context addresses the potential counter-argument that the Agreement's aim was merely to formalize the general application of provincial laws in Nouveau Québec.

Part 5 sets out the confidential strategic discussions of the Bourassa negotiating team on the Agreement, based on access to Robert Bourassa's archived dossier. This section reveals the strategic calculus at the heart of the Agreement, confirming much of what the theoretical literature sets out as the conditions under which transgression can occur. The negotiators ultimately decided against formally amending the division of powers, instead transgressing it on the assumption that a political equilibrium on the Agreement would hold given enough time. In Part 6, we examine the state of that equilibrium through a case in which litigants chose to pursue the s. 91(24) question in court-an early moment when the equilibrium had not totally taken hold. We look at a case in the early 1980s when Inuit groups opposed to the JBNQA put the question of federalism to the courts, only to subsequently withdraw the question. Other Indigenous parties have since litigated the Agreement, but not specifically on s. 91(24) grounds. We investigate such litigation by briefly considering the SCC's federalism review of the JBNQA in the 2010 Moses decision. We conclude that, as the SCC has not actually ruled on the JBNQA's validity on s. 91(24) grounds, it remains open whether Robert Bourassa's government has won the long game. The final Part concludes, returning to the federalism and judicial politics literatures.

It bears clarifying that we make no claims here regarding the actual constitutionality of the JBNQA. It is beyond the scope of this paper to provide an answer to the question of whether the Agreement was then or is now an unconstitutional transgression of the division of powers. In other words, this paper does not seek to answer whether the province's 1975 legal advice was then or still is sound advice. ${ }^{11}$ Of importance here is that provincial negotiators in

10 Henri Dorion, Rapport de la Commission détude sur l'intégrité du territoire du Québec (Québec (Province), 1967-1972) [“Dorion Report"].

11 Scholtz presents an argument on the JBNQA's contemporary constitutional validity in Christa Scholtz, "Treaty Failure or Treaty Constitutionalism?: The Problematic Validity of the James Bay and Northern Québec Agreement," University of Toronto Law Journal (forthcoming). 
1975 received advice from credible legal experts saying that the JBNQA was a clear transgression of the division of powers. The negotiators then acted as if they accepted that advice as sound, but then chose neither to seek formal constitutional amendment, nor a reference to the SCC on the constitutional question. Instead, they worked to insulate the Agreement from future litigation on the s. 91(24) question, and to make it strategically attractive for future judges to change, rather than enforce existing interpretations of, the division of powers.

\section{Transgressions as Rational: Expectations from the Political Science Literature}

Our interest here is a government's choice to act, despite its belief that a court is highly likely to invalidate that act. This section of the paper inserts our interest within the political science literature on federalism. We rely most heavily here on the theoretical work of Jenna Bednar. Bednar highlights that federalism's distribution of authority across central and sub-national governments needs to be defended in order to achieve the federation's goals. ${ }^{12}$ However, a federation successful over the long term also allows the distribution of power to evolve. In other words, a federation needs to respond strongly to overt government challenges to the distribution of authority, while not over-reacting to minor transgressions of that distribution.

This work pushes us to think less categorically and more ambivalently about transgressions. Bednar's work concludes that transgressions are both a rational and expected strategy of all governments within a federation, central and subnational alike. Given policy complexity, governments face inherent difficulties in deciding whether: 1) another government has actually transgressed the distribution of powers; and 2) whether a possible transgression is significant enough, in other words crossing some threshold, to merit costly intergovernmental enforcement. ${ }^{13}$ Bednar's model concludes that, given these difficulties, it is irrational for any government in a federation to fully comply with the division of powers. When the probability of a policy action being perceived as crossing an enforcement threshold is low, then it is better to deviate a little than to fully comply. Moreover, when the probability is high that a policy action will be perceived as significantly passing an enforcement threshold, then there can be a short-term value to transgressing: "the government may as well take as much as it can get in the short run, knowing that punishment is coming." 14 When Bednar extends the model to add judicial enforcement to intergovernmental enforcement, her conclusion changes only somewhat. Adding a judicial enforcer of the division of powers will decrease the extent of transgressions, but will not eliminate them entirely. In other words, the existence of strong and independent judicial review will help manage, but not fully deter, transgressive government behaviour. Bednar tells us that we should not be surprised that governments may choose to transgress when judicial invalidation is highly likely. ${ }^{15}$

Bednar, The Robust Federation, 55.

Ibid., 77.

Ibid., 82.

Ibid., 128. 
The recent game theoretic work by Gemma Sala builds on this literature, asking under what conditions the threat of judicial review will make governments comply with the division of powers in equilibrium. ${ }^{16}$ Sala's model is different than Bednar's. Sala builds a model of policy interaction between two governments, where a government wishing to enact a policy is uncertain about whether a court will veto the legislation if the other government chooses to litigate. In this game, two governments can choose to negotiate over a proposed policy, allowing for the possibility that one government will enact a transgressive policy that the other will not challenge in court. Sala's model predicts that governments can do so in equilibrium when a) the probability of a judicial veto is high; and $b$ ) the governments' policy preferences are sufficiently aligned so that there is a mutual interest in finding a compromise that keeps the non-enacting government out of court, despite the high probability of it winning. ${ }^{17}$ A key assumption in Sala's model is the absence of external litigants. Under this condition, governments cooperating in equilibrium can shield transgressive policies from judicial review.

These game theoretic frameworks of federalism encourage empirically-minded scholars to take transgressions seriously as a rational governmental response under certain conditions. Both Bednar and Sala help us understand why transgression can be an equilibrium strategy even when the threat of judicial invalidation is high. Sala points to the possibility that governments can coordinate transgression given sufficient overlap in policy incentives, and when there is no outside litigant. In the following sections, we build on the foundations of these theories. We describe the political context from which the JBNQA arose, explaining why Québec negotiators decided the province's long-term interests would be better served not just in pushing the boundaries of the division of powers, but in challenging it altogether.

\section{The BNA Act and Nouveau Québec before the Dorion Report} (1970)

The Indigenous peoples of the territories relevant to the JBNQA have their own vocabularies for these lands. In the settler imaginary of the 1970s, these lands are known as Nouveau Québec. They are 'new' because under the constitutional structure of the Dominion of Canada, Parliament transferred these lands from the Northwest Territories to the province of Québec over two periods. The first was in 1898 , extending the province's territorial boundary northward to the 52nd parallel. The second was in 1912, with Parliament then extending the provincial boundary to the Hudson Strait. ${ }^{18}$ Section 2 of the 1912 Act delegated the responsibility of negotiating any surrender of Indigenous interests in the territory-and the costs thereof-to Québec:

16 Sala, "Can Courts Make Federalism Work?," 193.

17 Sala theorizes that policy alignment may be the result of a shared electoral constituency or a shared party label. This is clearly not an exhaustive set of possibilities.

18 An Act respecting the north-western, northern, and north-eastern boundaries of the province of Quebec, 1898, 61 Vic, c 3; An Act to extend the boundaries of the Province of Quebec, 1912, 2 Geo V, c 45. 
2(c) That the Province of Québec will recognize the rights of the Indian inhabitants in the territory above described to the same extent and will obtain surrenders of such rights in the same manner as the Government of Canada has heretofore recognized such rights and has obtained surrender thereof and the said Province shall bear and satisfy all charges and expenditures in connection with or arising out of such surrenders.

(d) That no such surrender shall be made or obtained except with the approval of the Governor in Council.

(e) That the trusteeship of the Indians in the said territory and the management of any lands now or hereafter reserved for their use shall remain in the Government of Canada, subject to the control of Parliament.

Surrenders negotiated pursuant to the Act required the approval of the federal Governor in Council. Clause 2(e) appears to restate the division of powers. Upon the conclusion of any land surrender treaty, s. 91(24) would continue to apply to any "lands reserved for the Indians" within the territory. ${ }^{19}$ The geographic scope of s. 91(24)'s reach in Nouveau Québec rests on how one defines "lands reserved for the Indians." The Privy Council addressed the question in the 1888 St. Catherine's Milling ${ }^{20}$ case, concluding that the phrase, "according to [its] natural meaning," was "sufficient to include all lands reserved, upon any terms or conditions, for Indian occupation." In its view, "all such lands, and Indian affairs generally, shall be under the legislative control of one central authority." ${ }^{21}$ This expansive wording means that any such lands, defined either through treaty or statute or any other instrument, fall within the legislative ambit of Parliament. Provincial laws whose explicit purpose, or "pith and substance," is to regulate Indians or lands reserved for them would be ultra vires.

Québec declined to enter into land surrender negotiations in Nouveau Québec in the period after 1912. The 1912 boundary extension was not sufficient to entice the province to spread its administrative presence north for many years. After the collapse of fur prices and the trading economy in the 1930s, Québec was reluctant to assume the fiscal burdens of administering relief to the Inuit population in northern Québec. This reluctance led Québec to argue that the Inuit population in the province fell under federal jurisdiction, being "Indians" under the BNA Act. ${ }^{22}$ In 1939, the SCC accepted the province's argument, reasoning that Parliament's intention in 1867 was for "Indians" under s. 91(24) to mean "aborigines."

19 The same clause was included in the Ontario and Manitoba boundary extension acts of the same year. See An Act to provide for the extension of the Boundaries of the Province of Manitoba, 1912, 2 Geo V, c 32; An Act to extend the Boundaries of the Province of Ontario, 1912, 2 Geo V, c 40.

20 Note that the SCC decision in 1887 spelled "Catharine" with an "a" and the JCPC decision in 1888 spelled "Catherine" with an "e." We have reproduced the spelling was used by the jurisdictions we are citing.

21 St. Catherine's Milling and Lumber Company $v$ The Queen [1888] UKPC 70, (1889) LR 14 App Cas 46 at 11.

22 For an informed historical account of provincial and federal positions leading up to the 1939 reference, see the first chapter of Frank Tester and Peter Kulchyski, Tammarniit (Mistakes): Inuit Relocation in the Eastern Arctic, 1939-63 (Vancouver: UBC Press, 1994).

23 Reference whether "Indians" includes "Eskimo" [1939] SCR 104 at 116-7 [Re Eskimos]. 
Following the decision, the federal government began to establish a stronger administrative presence in Nouveau Québec by installing RCMP detachments at Inukjuak (Port Harrison) and Kuujjuaq (Fort Chimo). Over the course of the 1950s, the federal government started administering health and education policies for the Inuit and Cree. According to federal records, “... [u]ntil 1960 only the federal government had officials in this area; in that year the Québec Provincial Police established detachments in two settlements, and the R.C.M. Police were withdrawn." 24

Québec's interest in expanding its administrative reach north was marginal until the nationalist crucible of the 1960s. The provincial government could always have done so without any discussion with the federal government, as the provinces have constitutional authority over health and education. It was largely held that provincial laws of general application could have been used to assert Québec's administrative and jurisdictional presence over all of the peoples in Ungava, Indigenous or not. This view was confirmed in federal archival records: "although Parliament alone has the exclusive authority to make laws in relation to Eskimos, a province may, by properly framed laws relating to a matter coming within section 92 or 93 of the British North America Act, include Eskimos with other persons in the province for whom such services are provided. In fact, generally they cannot be excluded." 25

The beginning of the Quiet Revolution awakened the province's interest in asserting itself in Nouveau Québec. Bringing together policy change and cultural transformation, the Quiet Revolution bound state expansion and modernization to national identity. ${ }^{26}$ However, making such assertions real on the ground is financially costly. The "general application" approach, which we could characterize as a full compliance approach to the division of powers, gave rise to an important financial burden. Acting within the province's health and education jurisdiction would saddle Québec with the full financial costs of its northern expansion. A more financially attractive option was not to act directly within its own established jurisdictions, but to persuade the federal government to delegate its administrative (not jurisdictional) authority over Inuit to Québec. Under this strategic approach, financial responsibility would remain with the federal government per the political norm that legislative jurisdiction under s. 91(24) “...carries with it the responsibility of providing money to be devoted to the carrying out of policies in relation to the Indians." 27 From an analytical perspective, this alternative has the province deviating from a dualist federalism towards a point where the province muddies policy accountability by acting within federal jurisdiction as the federal government's

24 Memorandum to Cabinet titled "Eskimo Administration in Northern Québec," (14 February 1964), Ottawa, National Archives of Canada (RG 2, series B2, vol 6259, file 47-64, cabinet document number 47/64).

26 Daniel Béland and André Lecours, "Sub-State Nationalism and the Welfare State: Québec and Canadian Federalism," Nations and Nationalism 12, no. 1 (2006): 81.

27 Memorandum to Cabinet titled "Contributions to Newfoundland Respecting Indians and Eskimos," Appendix D, Justice opinion (14 April 1950), Ottawa, National Archives of Canada (RG 2, B26274, file 253-65). 
administrative agent. ${ }^{28}$ While this is not a violation of the division of powers, this is arguably a deviation from a dualist full compliance approach.

This cost-effective alternative did not go unnoticed by the federal government. In 1961, René Lévesque-provincial minister of natural resources and minister responsible for provincial administration in Ungava-opened an informal discussion with the federal government on the issue of the province "tak[ing] over the work carried out by the Department of Indian Affairs and Northern Development among the Eskimos in northern Québec." ${ }^{29}$ After starting this dialogue, Lévesque established a pilot training program for provincial administrators in Ungava in 1962. But federal officials identified a crucial limit on the effect of the training program: “...this move, however, loses much of its impact if it is restricted to the non-native people who form a very small part of the population." Turning to motive, the memorandum observed: “This probably goes far in explaining Mr. Lévesque's eagerness to assume responsibility for the administration of Eskimo affairs." ${ }^{30}$ In December of 1962, a formal letter broaching the topic was reportedly sent from Premier Lesage to Prime Minister Diefenbaker. The issue came to a head in early 1964, when René Lévesque demanded that “...the federal government hand over the administration of the Eskimos in this area to the government of Québec by April 1st, 1964."31

The matter came on the federal cabinet agenda in February 1964. The then minister for northern affairs and national resources, Arthur Laing, wrote a memo to cabinet on the issue. Québec sought administrative delegation of services to Inuit, but "also wanted the federal government to continue to pay." ${ }^{2}$ The federal cabinet considered it politically risky, although constitutionally justifiable, to reject Lévesque's request. In other words, federal enforcement of its administrative autonomy under s. 91(24) had its own political costs. The chief imperative of the federal government was to manage its political relationship with the Lesage government: "If Canada were to reject outright Québec's request and preserve the status quo, relations with the Québec government... would become severely strained.... Therefore, while this position would be constitutionally defensible, Québec's offer to administer Eskimo affairs should not be rejected outright." ${ }^{33}$ The Prime Minister noted that the issue needed to be handled delicately, because "the

28 See Jean-François Gaudrealt-Desbiens and Johanne Poirier, "From Dualism to Cooperative Federalism and Back?," in The Oxford Handbook of the Canadian Constitution, ed. Peter Oliver, Patrick Macklem, and Nathalie DesRosiers (Oxford: Oxford University Press, 2017), 396-97.

29 "Dossier on Eskimos - Northern Québec," prepared by T. McKee, Regina, First Nations University of Canada (Regina Campus) (Stewart Raby collection, box 22, file 3). T. McKee was the federal Administrator of Arctic Québec. McKee's document was forwarded to a Mr. L. G. Smith, Acting Head, Consultations, in an unnamed federal department. The cover letter indicates that McKee's dossier (itself undated) was circulated on April 30, 1970. Note that McKee was incorrect in that in 1961 the federal department to which he refers, and that was responsible for Eskimo administration in Northern Québec, was the Department of Northern Affairs and National Resources. DIAND was not so named until 1966.

30 Memorandum 47/64, "Eskimo Administration in Northern Québec."

31 Cabinet Meeting (17 February 1964), Ottawa, National Archives of Canada (RG 2, vol 6264, file 2).

32 Cabinet Meeting (18 February 1964), Ottawa, National Archives of Canada (RG 2, series A-5-a, vol 6264).

33 Memorandum 47/64, "Eskimo Administration in Northern Québec." 
issue was also a symbolic one in Québec as a result of the strong position taken by Mr. Lévesque." 34 The Prime Minister was thus advised that he might need to address the issue directly with Premier Lesage. ${ }^{35}$

Soon after, the governments drafted an agreement providing for Québec's transition to sole administrator of Inuit affairs by April 1970, with the federal government retaining a supervisory and cost-sharing role. ${ }^{36}$ It looked like Québec's move away from full compliance would pay off. However, the transition apparently did not go as planned. Indigenous political mobilization intervened in the aftermath of the Trudeau White Paper on Indian policy. The Inuit of Québec objected to an intergovernmental agreement reached without any community consultation. In 1969, the two governments dropped the April 1970 deadline and instead appointed a federal-provincial commission (the Neville-Robitaille Commission) with a mandate to consult with the Inuit of Nouveau Québec on the administrative transition. During consultations, the commissioners were clear with the Inuit that Québec's administrative role did not lessen the federal government's jurisdiction. To illustrate, the following is an extract from the meeting with Inuit in Ivujivik, on March 1, 1970. Mr. Robitaille, the provincial government representative, said:

In the 1930s, there were discussions as to who would take care of the Eskimos. It was brought to court and the Supreme Court decreed that Ottawa was going to supervise the Eskimos. This was said by Mr. Neville today here and also in the letter sent to the Eskimos. That is why Mr. Neville said that the federal government was going to continue to supervise services to the Eskimos in Northern Québec. But the federal government, while keeping jurisdiction, wants the province to administer these services. ${ }^{37}$

The Neville-Robitaille commission reported in 1970. The report is noteworthy for the resistance of the Inuit to idea of a sole provincial administrator, as well as their insistence that Inuit control over the lands on which they dwelled be addressed prior to any such administrative transfer. ${ }^{38}$

Our central take-away is that Québec pursued its mid-1960s administrative expansion by deviating somewhat from a full compliance strategy. The fiscal benefit of being the federal government's administrative agent clearly outweighed the political cost of supporting the federal government's legal jurisdiction while being its subordinate. This calculation would dramatically change in 1971.

34

Cabinet Meeting (18 February 1964)

Ibid. We should also note that Québec chose to make a symbolic issue of Inuit administration at the precise time that the new minister of justice, Guy Favreau, was presented with the option of engaging in an intergovernmental constitutional conference. Hence, the relationship with Premier Lesage would have been a top priority for the federal government. Memorandum prepared for minister of justice, from the deputy minister of justice, entitled "Constitutional amendments in Canada” (3 February 1964), Ottawa, National Archives of Canada (RG 2, series B2, vol 6262).

36 Page entitled "Understanding reached between the federal government and the government of the province of Québec, February 29, 1964" from McKee dossier (29 February 1964), Regina, First Nations University of Canada (Regina Campus) (Stewart Raby collection, box 22, file 3).

37 Neville-Robitaille Commission, Report of the Federal-Provincial Team of Officials Directed to Visit the Communities of Nouveau Québec, February-March 1970 (Ottawa: Department of Indian Affairs and Northern Development, 1970).

Ibid., 88 . 


\section{Administrative Delegation Is No Longer Enough: The JBNQA in the Shadow of the Dorion Report}

In 1966, Québec created the Commission on Québec's Territorial Integrity, chaired by University of Laval geographer Prof. Henri Dorion. While René Lévesque was pursuing his administrative position with respect to the Inuit in Nouveau Québec, the Dorion Commission went about its work under the radar. Five years after its inception, the Dorion Commission released the fourth volume of its final report, in March 1971. This volume specifically addressed the issue of Indigenous peoples and lands within Québec territorial borders. The Dorion volume marked a pivotal departure from the assumptions underlying Québec's previous strategy for northern expansion. Acting as the federal government's administrative agent, coupled with federal supervision and funding, was no longer a politically palatable means of securing the provincial state's role in Nouveau Québec.

The Dorion Report made two recommendations of direct relevance to this paper. First, the Report called on Québec to enter into negotiations with the federal government. It argued that the province's territorial integrity was threatened by the federal government's jurisdictional authority under s. 91(24). According to the Commission, securing Québec's territorial integrity required a new jurisdictional configuration: "La mise au point d'une politique d'ensemble en vue de promouvoir davantage la communauté amérindienne et harmoniser ses rapports avec la communauté québécoise ambiante exige l'ouverture immédiate de pourparlers entre les deux ordres de gouvernement aux fins de rendre possible la prise en charge par le Québec de la compétence sur les Indiens et les Esquimaux." ${ }^{39}$

Federal-provincial discussions were necessary for Québec's takeover of s. 91(24), and the Report endorsed the suggestions of the 1969 federal White Paper as a means to this end: “...que des pourparlers soient entrepris auprès du gouvernement fédéral pour que celui-ci mette à exécution dès que possible les propositions de son Livre Blanc à l'effet que la juridiction sur les Indiens et les Esquimaux du Québec soit remise au gouvernement du Québec." ${ }^{40}$ Other recommendations included replacing the federal reserve system with "Aboriginal municipalities," which would have the same rights as standard municipalities but would enjoy more protection. ${ }^{41}$ The Report also suggested convincing the federal government to give up all property rights-as well as territorial rights-related to Indian reserves. ${ }^{42}$ Indian lands were to be documented in a provincial government database and would be subject to Québec's law. ${ }^{43}$ It is clear that the Dorion Report recommended that the division of powers be changed, and that intergovernmental negotiations were required for this to happen. However, it is not clear whether

39 "Putting in place a comprehensive policy with a view towards better promoting the Amerindian community and harmonizing its relations with the surrounding Québec community requires the immediate opening of negotiations between the two levels of government in order to make it possible for Québec to take over the jurisdiction over Indians and Eskimos." Henri Dorion, 397, s 50. "... that negotiations should be undertaken with the federal government to put into operation as soon as possible the proposals of its White Paper, to the effect that jurisdiction over the Indians and Eskimos of Québec should be transferred to the Québec government.” Ibid., at 401, s 5. 
Dorion understood that its preferred outcome would require a formal amendment of the BNA Act.

According to the Dorion Report, Québec's territorial integrity remained weak so long as Indigenous peoples within its territorial boundaries had valid claims against the Québec state. The Commission thus identified a second key task for the province. The province was to enter into discussions with northern Indigenous peoples, as foreseen by the 1912 boundaries extension act, to address and potentially reach a settlement with respect to their rights and grievances. ${ }^{44}$ Soon after the release of the Dorion Report, the Premier met with the Association des Indiens du Québec (AIQ) to begin these discussions on a province-wide basis.

This sets the political scene for the introduction of the James Bay hydroelectric project. A month after the preliminary discussions with the AIQ had begun, the Bourassa government publicly announced its intention to build the James Bay hydroelectric complex. The issue of hydroelectric development had by then become deeply entwined with provincial nationalist state-building. The mantra of the age was maitres chez nous (masters in our own house). ${ }^{45}$ Autonomy was embodied in a hybrid of political, cultural and economic power. In due course, the nationalization of electricity was deemed Québec's economic "key to the kingdom." ${ }^{46}$ Importantly, Lesage's Liberal government had already passed laws establishing new Crown corporations and enlarging Hydro Québec. ${ }^{47}$ Daniel Johnson's Union Nationale government followed suit, creating Crown corporations aimed at resource development, and giving a green light to Hydro Québec's Churchill Falls scheme. ${ }^{48}$

Upon winning the 1970 provincial elections, Robert Bourassa's Liberal government remained committed to economic expansion. ${ }^{49}$ Bourassa's undertaking of the scheme was in keeping with the policies of his predecessors. ${ }^{50}$ However, the James Bay project represented an unprecedented and irrevocable expansion of the provincial state into Nouveau Québec.

\section{Negotiating the Agreement: Legal Context and Calculus}

The hydro plan became core to the discussions between Québec and the AIQ, with the AIQ demanding that the project not go ahead before a province-wide treaty was reached. ${ }^{51}$ This request was denied. Québec would not entertain delays to the

44 Ibid., 401. Recommendation 2 reads "que l'accomplissement de cette obligation prenne la forme d'une entente entre le gouvernement du Québec et les représentants, dûment mandatés, des bandes indiennes du Québec, entérinée par le gouvernement du Canada" (that fulfillment of this obligation should take the form of an agreement between the government of Québec and the duly mandated representatives of the Indian bands of Québec, ratified by the government of Canada). This was the Liberal Party of Québec's campaign slogan during the 1962 provincial election.

Caroline Desbiens, "Producing North and South: A political geography of hydro development in Québec," The Canadian Geographer 48, no. 2 (2004): 105.

Richard Simeon and Ian Robinson, State, Society, and the Development of Canadian Federalism (Toronto: University of Toronto Press, 1990), 179.

Ibid., 180.

Ibid., 181.

Caroline Desbiens, “'Water All Around, You Cannot Even Drink': The Scaling of Water in James Bay/Eeyou Istchee," Area 39, no. 3 (2007): 262.

Memo titled "Note aux commissaires" from Jean-Paul Lacasse, Secretary to the Commission de négociations des affaires indiennes (6 May 1971), fonds Robert Bourassa, 1987-07-001/166, dossier 6 [1 of 3]). 
proposed James Bay project. In July, it passed Bill C-50, the James Bay Region Development Act, creating the Société de développement de la Baie James (SDBJ) as the entity mandated to manage the project. ${ }^{52}$ While the SDBJ organized to develop the project's early work, discussions with the AIQ plodded on with no progress on the James Bay project.

In early May 1972, the AIQ_now joined by the Inuit-turned to litigation. At the Québec Superior Court, they argued that the James Bay Region Development Act was ultra vires the province's legislative authority. ${ }^{53}$ Interestingly, the case was deliberately filed as a federalism case, not an Aboriginal rights case. In the words of Cree Chief Billy Diamond, “...Indians rights were being held in reserve for another court action at a later date." ${ }^{\text {}}$ Six months after initiating proceedingsfrustrated by fruitless discussions with the province-the plaintiffs sought an interlocutory injunction to stop work on the project while their federalism claim was before the courts. The injunction was to stop the hydro project on the basis of its negative impact on Cree and Inuit traditional livelihoods. In November 1973, Justice Albert Malouf famously granted it. ${ }^{55}$ Justice Malouf's injunction was almost immediately overturned by the Québec Court of Appeal, although that reversal had no effect on the underlying federalism claim still before the courts. Nonetheless, the short-lived Malouf injunction seemed to have roused the provincial government. Bourassa subsequently replaced his chief negotiator with a member of his legislative caucus, appointing Hon. John Ciaccia to this critical role.

In November 1974, one year after his appointment, Ciaccia delivered an agreement in principle (AIP) with the Grand Council of the Crees, the Northern Québec Inuit Association, the provincial government, the various provincial entities involved in the project, and the federal government. ${ }^{56}$ The AIP committed the Inuit and Cree to surrender their Aboriginal title to the lands under the 1898 and 1912 boundary extension acts, to allow the James Bay project to proceed, and to drop their federalism litigation against the James Bay Region Development Act. In return, the province agreed to technical modifications of the project, a financial compensation package, a new land and rights regime, and the establishment of Cree and Inuit governance and administrative institutions. Importantly, the AIP purported to secure Québec's legislative jurisdiction over the lands on which the Inuit and Cree had negotiated treaty rights. ${ }^{57}$ The AIP thus went well beyond the administrative delegation the province had sought in the 1960s.

52 James Bay Region Development Act, SQ 1971, c 34.

53 Chief Kanatewat et al. v. Attorney General of Québec, filed in the Québec Superior Court on 2 May 1972.

54 Unpublished and undated monograph by Billy Diamond titled "Highlights of the Negotiations Leading to the James Bay and Northern Québec Agreement" (held in the McGill University Library collection since 1979). Citation is from page 7 of the monograph.

55 Gros-Louis et al. c. Société de développement de la Baie James (1973), [1974] R.P. 38 (C.S.), 8 C.N.L.C. 188.

56 In April 1974, the James Bay Cree revoked the AIQ's negotiating mandate. The Crees formed and subsequently incorporated the Grand Council of the Crees of Québec as their representative at the negotiating table.

57 Section 5.1.3. states that category 1B lands whose ownership vests in Cree corporations, are "under provincial jurisdiction." Section 5.2.1. states that "provincial jurisdiction shall continue over category II [Cree] lands." Section 7.1.5. reads that "category I [Inuit vested] lands shall be under provincial jurisdiction." Section 7.2.1. reads that category II Inuit lands "shall remain under provincial jurisdiction." 
Between the signing of the AIP and the signing of the Final Agreement, the draft agreement was examined by various lawyers. Robert Bourassa's files contain four separate legal opinions on the AIP. The first was from the "legal committee"; 58 the second was the internal legal advice of the SDBJ; ${ }^{59}$ the third was the internal opinion of the provincial Ministry of Justice; ${ }^{60}$ and the fourth was an outside opinion, written by a provincial court judge. ${ }^{61}$ The four opinions share the same bottom line. All advised that the agreement as negotiated was ultra vires provincial jurisdiction. We thus arrive at the constitutional question posed by s. 91(24). What happens when a treaty-an intergovernmental agreement-tries to extend provincial jurisdiction over "Indians, and Lands reserved for the Indians"?

The legal committee opinion set out the basic problem, and outlined what it saw as the possible courses of action going forward. Here, the legal problem was described in this way:

The key principle of the Agreement in Principle is the guarantee to the native parties of certain legal safeguards while preserving the continuance of Provincial jurisdiction in the areas concerned...The dilemma of the Legal Committee revolves around the desire to preserve the continuance of Provincial jurisdiction over all lands affected by the Agreement in Principle (with the exception of those lands referred to as Category 1A lands), as well as to ensure the jurisdiction of the Province in matters affecting the native peoples pursuant to the Agreement in Principle. ${ }^{62}$

The chief obstacle was the definition of "lands reserved for the Indians" as set out in St. Catherine's Milling: "sufficient to include all lands reserved, upon any terms or conditions, for Indian occupation." To the extent that the proposed Agreement provided for "Indian occupation" beyond Category IA lands, it would have the effect of expanding the reach of s. 91(24) over those very lands. The lawyers warned that the terms of the treaty would have the (from the province's point of view) perverse effect of expanding federal jurisdiction, rather than erasing it. The legal committee noted that, while "no precedent has been found in the jurisprudence dealing with the legislative authority of a province in relation to Indian lands which have not yet been set aside as reserves under the Indian Act...the wide St. Catherine's Milling interpretation of S. 91(24) does not appear to admit any exceptions in favour of this particular case as such."63

The legal committee also identified a second risk, which asked whether provincial laws of general application could apply to "lands reserved" under s. 91(24) at all. This concern arose from a dissent by Chief Justice Bora Laskin in a hunting

58 Legal Committee Position Paper: Legal Means for Securing the Constitutional Validity of 'The Final Agreement' (3 June 1975), fonds Robert Bourassa, 1987-07-001/166, dossier 6 ["Legal committee opinion"].

Memo titled in part "Annex II: CONSIDÉRATIONS LÉGALES," by the legal counsel of the SDBJ (25 July 1975), fonds Robert Bourassa, 1987-07-001/166, dossier 6 ["SDBJ opinion"].

60 Memo titled "Négociations Indiens-Inuit, Baie James," written to the Deputy Minister of the Ministry of Justice (18 September 1975), fonds Robert Bourassa, 1987-07-001/166, dossier 6 [“Justice opinion"].

61 Memo titled "Sujet : Entente finale avec les autochtones de la Baie James" (31 October 1975), fonds Robert Bourassa, 1987-07-001/166, dossier 6 ["Provincial judge opinion"].

62 Legal committee opinion, emphasis in the original.

63 Ibid. 
and treaty rights case from Alberta, Cardinal $v$ Attorney General (Alberta). ${ }^{64}$ The key question in Cardinal was the degree to which provincial game laws, i.e., laws of general application, could apply on reserves defined as such under the federal Indian Act. In his dissent, Justice Laskin relied on St. Catherine's Milling to argue that such reserves were enclaves "withdrawn from provincial regulatory power." 65 The court's majority rejected this enclave interpretation, and it was subsequently criticized in legal scholarship. ${ }^{66}$ However, the legal committee viewed Cardinal as upholding the wide definition of "lands reserved for Indians" and providing "additional doubt of whether even generally applicable provincial laws can incidentally affect Indians or Indian lands." committee expressed its hesitations as follows: "This constitutional state of affairs, coupled with the Provincial interpretation of 'the continuance of Provincial jurisdiction' as including both legislative and administrative competence in the areas and matters affected by the Agreement in Principle, have caused the Legal Committee great anxiety and serious doubts in its attempts to formulate legal means for securing the constitutionality of 'the Final Agreement."'

The legal committee then turned to reviewing the provincial government's options in light of this anxious situation. The first was to seek "the surest of all legal solutions": a constitutional amendment of s. 91(24) of the BNA Act by the British Parliament. This, however, was seen as politically unfeasible. Therefore, the legal committee did not even suggest wording for a formal amendment. The second option was to amend the 1912 Québec boundaries extension act, hoping to rid the province of the burdens imposed by s. 2(c) and s. 2(e) of that act. However, they noted that the effect of the repeal was unknown, as it would not change s. 91(24) of the BNA Act. The option of federal referential legislation might have worked in transferring administrative competence to the province but was vulnerable to future revocation by Parliament. Moreover, it was "...insufficient for the desire of the Province to have continued legislative as well as administrative jurisdiction in the areas concerned." The last option was for the federal government to establish "ethnic" native corporations, but the committee said that this presented "extensive technical difficulties" and was not a "viable solution." As a result, the committee concluded that there was no way "...to secure the constitutional validity" of the agreement in the absence of a formal constitutional amendment.

The three opinions following the legal committee opinion shared the same basic read of the law in 1975. The legal committee at SDBJ pointed to constitutional amendment, arguing that “...l'amendement à la Constitution par Londres était la seule solution acceptable." 68 The Ministry of Justice found that "la position constitutionnelle du Québec est intenable," ${ }^{69}$ relying again on St. Catherine's Milling:

64 Cardinal v Attorney General (Alberta), [1974] SCR 695 [Cardinal]. Although Justice Laskin became Chief Justice in 1973, he writes as a puisne justice in Cardinal. Justice Laskin was joined in the dissent by Justices Emmet Hall and Wishart Spence.

65 Cardinal, 716.

66 See Peter W. Hogg, Constitutional Law of Canada (Toronto: Carswell, 1977), 387.

67 Legal committee opinion, 3.

68 "The amendment of the Constitution by London was the only acceptable solution."

69 "Québec's constitutional position is untenable." 
Je suis d’opinion que les terres des catégories I, II et III sont toutes des "terres réservées" au sens de l'article 91(24) de la Constitution puisqu'elles sont toutes réservées pour l'occupation indienne et le jugement du Conseil privé dans la cause de St. Catherine's Milling ne précise pas s'il s'agit d'une occupation exclusive ou non, mais il précise qu'il s'agit d'une occupation suivant n'importe lequel (sic) terme ou condition. ${ }^{70}$

According to the Ministry, most lands under the JBNQA were "lands reserved for Indians," thus falling under federal jurisdiction. Similarly, the provincial judge's opinion concluded that Québec's position was "carrément anticonstitutionnelle."71 Should the agreement go to the courts, it was his conclusion that "le Québec verrait une très grande partie de son territoire tomber sous juridiction fédérale." ${ }^{72}$ Deeming the JBNQA unconstitutional, the judge surmised that the territories under the Agreement were at risk of falling to the federal government in the event of litigation. Québec stood to lose the very jurisdiction it sought to consolidate.

Given the above legal advice, what were provincial negotiators to do? According to the legal advice, the AIP was a slam-dunk transgression of the division of powers. The authors of the SDBJ opinion recounted how, in response to this advice, provincial negotiators began exploring the possibility of inserting a delayed cancellation clause within the draft Agreement, whose chief purpose was to dissuade any Indigenous party from litigating the issue. This clause would prescribe that, in the event of a court concluding that category IB, II and III lands were "lands reserved for the Indians," the lands would go back to Québec and would be freed from Canadian or Indian rights after two years. Should this happen, Canada and Québec committed themselves during the two-year window, "de façon formelle à prendre les dispositions nécessaires, incluant l'amendement à la Constitution Canadienne par Londres si nécessaire....73 This, of course, would not be as secure as getting the constitution amended prior to the signing of the final agreement, but it would have to do. Ultimately, the proposed clause was included in the Agreement, as section 2.10. ${ }^{74}$

Québec indisputably took a gamble on the JBNQA. The decision to take the plunge was a calculated risk. The province wanted to move ahead quickly with the James Bay project, as delays increased its already significant cost. It also wanted to stop the existing litigation on the constitutionality of Bill C-50. However, the Cree were absolutely insistent that the Final Agreement be signed by November 11, 1975-all their chartered flights and helicopters were flying home on the twelfth. ${ }^{75}$

70 "It is my opinion that the lands in categories I, II and III are all 'lands reserved' in the sense of section 91(24) of the Constitution because they are all reserved for Indian occupation. The judgment of the Privy Council in the St. Catherine's Milling case does not specify whether occupation must be exclusive or not, but it does specify that it concerns occupation on any terms or conditions."

71 “...clearly unconstitutional."

72 "Québec would see a very large part of its territory fall under federal jurisdiction."

73 "formally to take the necessary steps, including an amendment to the Canadian Constitution by London if necessary."

74 Section 2.10 of the JBNQA has never been amended, as verified by the consolidated Agreement, accessed at http://www3.publicationsduquebec.gouv.qc.ca/produits/conventions/lois/loi2/pages/ page4.en.html via paid subscription on September 2, 2019.

75 Billy Diamond, "Highlights of the Negotiations Leading to the James Bay and Northern Québec Agreement," 42. 
The James Bay Cree and Inuit were prepared to sign the deal before then. Pursuing a constitutional amendment would take a lot of time, with no guaranteed results. Indeed, we found no archival documentation showing that provincial negotiators thought a constitutional amendment was ever a feasible option.

The deal needed to go ahead in November 1975, whatever the risks. And so the signatories proceeded accordingly. Going forward, the key to making the Agreement work was to dissuade litigation but also, and centrally, to build public and media opinion in favour of the Agreement. A portion of the judicial politics literature argues that there is a correlation between Supreme Court decisions and public opinion. Specifically, some scholars argue that judges are attuned to prevailing public sentiment. ${ }^{76}$ Archival evidence shows that negotiators encouraged the Bourassa government to take the risk precisely because they thought that public opinion in favour of the Agreement could be secured. The courts would thus bend to the winds of public opinion and would uphold the legislation:

I believe that even the Courts are influenced by public opinion. If the press continues to criticize the Province's treatment of the Native people in James Bay and calling for a halt of the project, this will definitely influence at least the English speaking members of the Bench - including the Supreme Court...A public statement must be made by the Government of Québec.... This statement must reflect an enlightened attitude by the Government in its treatment of Native people. This will be a first for Québec and will gain respect and the support of all of the people of Canada. If this is done there will be less cause for concern before the courts. ${ }^{77}$

In their eyes, to litigate against the JBNQA would benefit no one. Québec would lose its jurisdictional expansion, Ottawa would aggravate an already tempestuous relationship with the increasingly nationalist province, the Cree and Inuit would risk losing their treaty rights, and the courts would-as speculated by the negotiatorslose their public legitimacy. The players put their faith in a climate of public pressure and nationalist politics. The Bourassa government took a gamble and bet that the Agreement would ultimately be won through its political support, and that courts would eventually mould their doctrinal decisions to the realities of politics.

The JBNQA was given effect through both federal and provincial legislation. ${ }^{78}$ It was the first modern comprehensive land claim agreement, and has structured

76 Kevin T. McGuire and James A. Stimson, “The Least Dangerous Branch Revisited: New evidence on Supreme Court responsiveness to public preferences," Journal of Politics 66, no. 4 (2004): 1018; William Mishler and Reginald S. Sheehan, "The Supreme Court as a Countermajoritarian Institution? The Impact of Public Opinion on Supreme Court Decisions," American Political Science Review 87, no. 1 (1993): 87; Michael W. Giles, Bethany Blackstone, and Richard L. Vining, Jr., "The Supreme Court in American Democracy: Unraveling the linkages between public opinion and judicial decision making," The Journal of Politics 70, no. 2 (2008): 293. For a more recent assessment of the many factors affecting the decision-making of constitutional courts, see Georg Vanberg, "Constitutional Courts in Comparative Perspective: A Theoretical Assessment," Annual Review of Political Science 18 (2015): 167.

77 Memo to Robert Bourassa, entitled "The James Bay Project and Native Claims."

78 The Agreement was first enacted through An Act Approving the Agreement Concerning James Bay and Northern Québec, SQ 1976, c 46, RSQ c C-67, and the James Bay and Northern Québec Native Claims Settlement Act, SC 1976-77, c 32, RS c J-o3. Other provincial legislation includes The Cree Villages and the Naskapi Village Act, SQ 1978, c 88, RSQ c V-5.1, and An Act Respecting the Cree Regional Authority, SQ 1978, c 89, RSQ c A-6.1. 
the legal and administrative relationship between the Inuit and James Bay Cree since. It has also been renegotiated, increasing the expansion of Cree governance authority over category II and III lands.

\section{The JBNQA and Federalism Review: An Open Constitutional Question}

The goal in this penultimate section is to substantiate a simple claim: that the core constitutional question at the heart of the JBNQA remains an open one, more than four decades after its signing. The expansion of hydroelectric development in the Agreement's territories has subsequently been litigated in the lower courts, but the decisions in these cases have not called into question the Agreement's validity on s. 91(24) grounds. ${ }^{79}$ First, we set out what we have learned about an early legal challenge to the Agreement. Second, we outline the conclusions of the SCC in the single federalism decision on the Agreement: the 2010 Moses decision.

It is well known that not all Indigenous peoples from Nouveau Québec were satisfied with the JBNQA upon its signing. Those dissatisfied included the Inuit communities of Povungnituk, Ivujivik, and Saglouc. The inhabitants of these communities-constituting roughly a third of the Inuit population in Nouveau Québec-were known as the "Inuit dissidents of Nouveau Québec" by virtue of their refusal to sign onto the JBNQA. ${ }^{80}$ From their perspective, to recognize the Agreement “... serait reconnaître l'abandon de leurs droits aborigènes." 81 An article published in Le Soleil on December 16, 1981, describes Inuit communities intending to take legal action against the Agreement:

C'est ainsi qu'hier à loccasion d'une importante conférence de presse, leurs représentants ont annoncé qu'ils contesteront devant les tribunaux, bien sûr la légalité de cette convention qui a en quelque sorte, permis le développement hydro-électrique de la baie James, mais aussi la validité de toutes les lois fédérales et provinciales qui en ont découlé en plus de la constitutionnalité même de la cession en 1912 par le gouvernement fédéral de cet immense territoire (Terre de Rupert) qui avait doublé la superficie du Québec. ${ }^{82}$

We were able to locate indirect evidence of these proceedings in a July 1982 Québec Superior Court decision by Justice Walter Austin Johnson, relating to the authority

79 See for instance Hydro-Québec v Canada (Attorney General) and Coon Come, [1991] 3 CNLR 40, Cree Regional Authority v Canada (Federal Administrator), [1991] 2 FC 422 (TD), and at appeal [1991] FCJ No. 426. In the case at the Federal Court of Appeal, the justice at para 42 explicitly set out that his decision did not rely on s 91(24). Also, Eastmain Band v Canada (Federal Administrator) (CA), [1993] 1 FC 501.

80 Vie ouvrière, Les nations autochtones parmi nous, Dossier 134, avril 1979, at 206-7; "Des Inuit ne voteront pas," Le Soleil, dissidents du Nouveau Québec," Le Soleil, 17 March 1980, at B-2 ("les Inuit dissidents du Nouveau-Québec).

81 "would be to recognize the renunciation of their Aboriginal rights." Léonce Gaudreault, "Limpatience gagne les Inuit dissidents," Le Soleil, 1 November 1979, at B-5.

82 "So yesterday, during an important press conference, their representatives announced that they would contest in court not only the legality of this agreement, which in a way allowed the hydroelectric development of James Bay, but also the validity of all federal and provincial laws following from it, as well as the 1912 surrender by the federal government of this immense territory (Rupert's Land) that doubled the size of Québec." Léonce Gaudreault, "Les dissidents de la baie James reprennent la lutte," Le Soleil, 16 December 1981, C1. See also Léonce Gaudreault, "Dissidence chez les Inuit : Le Québec accuse de saboteur sa convention,” Le Soleil, 23 December 1981, D1. 
of the Kativik School Board created under the JBNQA. ${ }^{83}$ The following is a timeline of events that is reconstructed from Justice Johnson's written decision. Sometime in 1981, the dissenting communities of Povungnituk and Ivujivik objected to the Kativik School Board operating schools in those communities. The communities asked the provincial government to operate the schools instead. In November 1981, the provincial government subsequently issued an Order in Council, asserting its authority under the Loi sur le Ministère de l'Éducation to displace the Kativik School Board. The Kativik School Board litigated the issue. ${ }^{84}$ In April 1982, Justice John Hannan nullified the Order in Council, deciding in effect that the enactment of the JBNQA removed the government's authority to displace the Kativik School Board. A group of parents whose children attended the schools in question subsequently sought to suspend Justice Hannan's decision. This group of parents were part of a larger dissenting group who had commenced a legal action in December 1981, arguing in that action that the JBNQA and all of its enacting legislation were ultra vires. ${ }^{85}$ In Justice Johnson's courtroom, these parents argued that Justice Hannan had not had the benefit of hearing their constitutional arguments, and hence the Order in Council should continue to be in force. Justice Johnson denied the parents their petition, arguing in effect that the JBNQA would be presumed constitutional until a court determined otherwise: "The resistance to [the JBNQA] and the problems arising therefrom may apparently continue but, in the light of the existing legislation until the merits of the constitutional questions raised in the said action and in the present motion have been decided the parties involved will have to work within the framework of that legislation." 86

This raises the question of what finally came of the dissenting communities' constitutional arguments. Here the trail of publicly accessible sources runs cold. There is no reported judicial decision that we could find. Also, the file associated with Justice Johnson's 1982 decision, which would have included the relevant supporting documentation on the 1981 case, was destroyed as part of the usual

83 Kativik (Commission scolaire) v Québec (Procureur général), 1982 CarswellQue 254, [1982] 4 CNLR 54, JE 82-901 [Kativik].

84 Loi sur le Ministère de l'Éducation LR M-15, s 5, AC 2899-80.

85 Justice Johnson cites the core constitutional arguments of the petitioners before him as: "12-DECLARER ultra vires, illégale, nulle et non avenue la Convention intervenue le 11 novembre 1975 entre le Gouvernement du Québec, la Société deénergie de la Baie James, la Société de développement de la Baie James, la Commission hydro-électrique du Québec (Hydro-Québec), le Grand Council of the Crees (of Québec), la Northern Québec Inuit Association et le Gouvernement du Canada, Convention produite comme pièce P-1. 12-B) SUBSIDIAIREMENT, et sans préjudice à la généralité de la conclusion précédente, déclarer ladite convention illégale, nulle et non avenue et inopérante quant aux demandeurs et aux territoires des villages de Povungnituk, Ivujivik et Saglouc situés dans le territoire du Nouveau-Québec." "“12-DECLARES ultra vires, illegal, null and void the Agreement reached on 11 November 1975 between the Government of Québec, the James Bay Energy Corporation, the James Bay Development Corporation, the Québec HydroElectric Commission (Hydro-Québec), the Grand Council of the Crees (of Québec), the Northern Québec Inuit Association, and the Government of Canada, Agreement produced as exhibit P-1. 12-B) ALTERNATIVELY, and without prejudice to the generality of the preceding conclusion, declares the said agreement illegal, null and void and inoperative with respect to the plaintiffs and to the territories of the villages of Povungnituk, Ivujivik and Saglouc, situated in the territory of Nouveau Québec.") Kativik, 8, 9. 
judicial document management process approved by the courts and the Minister of Justice. ${ }^{87}$ In the absence of a judicial decision on the constitutional question, we might reasonably conclude that the litigation was withdrawn. We do know that no decision on the merits of the constitutional question made its way through the courts of appeal.

The only federalism case on the Agreement to reach the Canadian Supreme Court was Québec (Attorney General) v Moses in 2010. Moses concerned the JBNQA's provisions addressing environmental assessment procedures for future development projects. The case involved a mining company which sought to develop a vanadium mine on category III land, which would have negative environmental side effects. The mine proponent engaged the provincial environmental assessment procedure under the Agreement. The question before the Court was whether the mine proponent was additionally required to submit to a federal environmental assessment, under auspices of the Canadian Environmental Assessment Act (CEAA), before obtaining a federal permit to harm a fish habitat. The CEAA is federal legislation of general application, and was not in existence when the JBNQA was negotiated and enacted. The case asked the SCC to examine the status of the Agreement; how to interpret the text of the Agreement; whether the Agreement was consistent with federal environmental statute; and, if inconsistencies existed, whether the Agreement was paramount. The court split five to four, with the majority finding that the mine operator was indeed subject to an additional assessment under the CEAA.

We note at the outset that none of the parties in the case made an argument before the court casting doubt on the Agreement's constitutional validity. In their facta, they mounted no argument that the Agreement itself was an unconstitutional expansion of provincial powers over "Indians and lands reserved for Indians." The argument that so concerned Bourassa's legal advisors in 1975 was not put directly in front of the court in Moses. The court did not conduct a comprehensive assessment of the Agreement's constitutionality on all possible federalism grounds, and such a thing was not to be expected. However, the majority and dissenting opinions are interesting given the degree to which they draw broad federalism conclusions on the basis of the limited federalism review in this case.

We start with the opinion of the dissenting minority, penned by Justices Louis LeBel and Marie Deschamps. ${ }^{88}$ The dissent categorizes the JBNQA as "both an intergovernmental and an Aboriginal rights agreement," that it is "binding" on its parties, and that it "may be viewed as a model for the many modern land treaties that have been signed since the 1982 constitutional amendments." ${ }^{\prime 9}$ The minority also observes that the agreement "settles and determines the obligations, in relation to the Territory, of the federal and provincial governments as between themselves" "90 and as such is "therefore yet another example of what this Court has repeatedly called 'co-operative federalism." ${ }^{\text {"91 }}$ Importantly, the minority asserts the

Confirmed via e-mail correspondence with the $\mathrm{BAnQ}$, on file with the authors.

The minority position was held by LeBel, Deschamps, Abella, and Charron JJ.

Moses, para 82.

Ibid.

Ibid., para 84. 
following: "The Agreement, which is of course both a s. 35 treaty and an intergovernmental agreement that was made binding by way of statutory implementation, involves no inappropriate delegation of jurisdiction or legislative authority." 92

How did the minority's position compare with that of the majority? ${ }^{93}$ The first point we note is that Justice Ian Binnie, writing for the majority, also accepts the Agreement as a treaty protected under s. 35 of the Constitution Act, 1982. ${ }^{94} \mathrm{He}$ notes that "the James Bay Treaty was an epic achievement in the ongoing effort to reconcile the rights and interests of Aboriginal peoples and those of non-Aboriginal peoples in Northern Québec." 95 There is a broad acceptance of the fundamental validity of the Agreement itself and of its enabling legislation, both federal and provincial. However, Justice Binnie does not go so far as to echo the dissenting minority's broad assertion that no improper legislative delegation occurs anywhere within the text of the Agreement. But, like the minority, the majority holds that the Agreement was meticulously negotiated by parties well represented by legal counsel, and that the justices are to pay close attention to the text itself. ${ }^{96}$

The majority and the minority essentially split on where their respective interpretations of the Agreement's text lead them. The outcome where the federal fisheries minister is obliged to issue a permit upon provincial approval of a mine project is, for the minority, an acceptable outcome of cooperative federalism in the context of a supra-legislative agreement. For the majority, this is not an acceptable outcome, for this would effectively render the federal minister a delegate of the province. Justice Binnie writes: "I do not agree that the terms of the Treaty support such an anomalous result," make it "a vehicle for provincial paramountcy." Instead, he argues that the CEAA environmental assessment provision is not, in his reading, inconsistent with the Treaty and so should be allowed to operate. ${ }^{99}$ In the event that the "makers of the Treaty had intended the [provincial] Administrator's approval (or Cabinet's substituted approval) to be the end of the regulatory requirements, they would have said so, but they did not." ${ }^{\prime 100}$ But Justice Binnie does not explicitly say whether the majority would have endorsed the Treaty as a vehicle for provincial paramountcy, had either the text or extrinsic evidence not allowed for any other interpretation.

\section{Conclusion}

Jenna Bednar's work gives us theoretical grounds for expecting governments to transgress the division of powers, even under a high probability that a

\footnotetext{
92 Ibid., para 138. Emphasis added.

93 The majority in Moses was McLachlin CJ and Binnie, Fish, Rothstein, and Cromwell JJ.

94 Moses, para 15

95 Ibid.

96 Binnie J citing the dissent affirmatively on this point in para 7. On the point of interpretation, and the role of a close textual reading in modern treaty interpretation in Moses and Little Salmon/ Carmacks, see Dwight Newman, "Constitutional Cases 2010: Contractual and Covenantal Conceptions of Modern Treaty Interpretation,” Supreme Court Law Review 54, no. 2 (2011): 475.

97 Moses, para 3.

98 Ibid., para 13.

99 Ibid.

100 Ibid., para 37.
} 
transgressive policy would fail judicial review. Gemma Sala's work allows for governments to coordinate on a transgressive outcome under the same condition. The empirical case of the James Bay Northern Québec Agreement lends support to these scholars' theoretical contributions. The Agreement signatories considered both the immediate and long-term gains to completing the Agreement too important to walk away from. Given their impatience, what economists would call a high discount factor, negotiators preferred probable transgression over seeking formal constitutional amendment. The negotiators' chief strategy was to inoculate the Agreement from future litigation, chiefly by prohibitively raising the signatories' costs of litigating the s. 91(24) question via the Agreement's inclusion of s. 2.10. Stepping beyond Bednar's and Sala's work, this empirical account also shows the provincial negotiators relying on a strategic theory of judicial decision-making in the event that their inoculation measure should eventually fail. They speculated that given enough time, the court would shift its enforcement threshold. In other words, they predicted that the Supreme Court would change the law to save a popular and politically functioning Agreement, rather than invalidate it to enforce its existing interpretation of the division of powers.

The scholarship dealing with the Agreement has not been silent on the nationalist motivations driving Québec to sign onto the treaty. However, research on the constitutional difficulty the provincial negotiators identified at the core of the Agreement is conspicuously absent. Our work here is the first to draw on archival data from Bourassa's first government, and the first to set out that the negotiators of the Agreement were absolutely aware that they were taking a constitutional risk. We set out the goals, speculations, and strategies of provincial negotiators reporting to Robert Bourassa, confirming that the province understood itself to be in a strategic relationship with potential future litigants, courts, and public opinion, and how the Agreement was shaped by that strategic understanding. Conscious of the constitutional question at the heart of the Agreement, Québec's negotiators took a gamble by speculating that the land claim agreement could evade judicial review so long as the political equilibrium with the Cree, the Inuit, and the public, held. To some degree, Bourassa has been proven right, in that the core constitutional question has not be squarely decided in the courts. But until it is - until a future Supreme Court rules to uphold the Agreement as written on s. 91(24) grounds-the gamble is still in play. In the here and now, the Agreement and the statutory authorities to give it effect are presumed to be constitutional; what this historical examination of the Agreement's negotiation shows is that its negotiators considered that presumption rebuttable.

This begs many further questions, including whether Bourassa's gamble was replicated across the modern comprehensive land claim settlements which have been concluded since, elsewhere in Canada. It is one that we cannot thoroughly answer here with a broad canvas of all post-JBNQA land claim agreements. However, there is reason to surmise the gamble was Bourassa's alone. As Parts 4 and 5 of this paper laid out, Québec sought to use the James Bay treaty negotiations to expand provincial legislative authority vis-à-vis federal legislative authority in a very specific nationalist political context. In glaring comparison with the JBNQA, the Nisga'a Final Agreement explicitly sets out that it "does not alter the 
Constitution of Canada, including...the distribution of powers between Canada and British Columbia." ${ }^{101}$ The British Columbia Court of Appeal used this declaration to uphold the constitutional validity of the Nisga'a Agreement in the face of a constitutional challenge brought by some members of the Nisga'a nation. ${ }^{102}$ And while the British Columbia Court of Appeal in that case agreed that treaties could not be used to effect an inter-delegation of power as between Parliament and the provincial legislatures, treaty agreements could effect a delegation of legislative powers from Parliaments and legislatures to a "subordinate" Indigenous body set out within that treaty agreement. ${ }^{103}$

As we set out in the introduction, it is beyond the scope of this paper to develop an argument about whether Québec's contemporary legal advisors, on the basis of today's constitutional text and judicial precedents, would reach the same conclusion as their legal predecessors had in 1975: invalidity on s. 91(24) grounds. We have also refrained from speculating on what a present or future court would decide, should it actually accept the burden of answering the question. However, given the undeniable centrality of the Agreement to Indigenous-settler relations in Québec, we do think the following assertion is in order: that the SCC would be highly interested in a line of argument that would allow it to uphold the Agreement. Indeed, the SCC made much of its wish to encourage intergovernmental and Indigenous bargaining, after all. ${ }^{104}$ The question will be whether upholding the JBNQA would require the SCC to unsettle federalism's division of powers, a central component of our "constitutional architecture," ${ }^{105}$ in order to uphold this "epic agreement." If s. 91(24)'s push met the Agreement's shove, what would the SCC do? Bourassa's negotiators had a theory of what it would do. It remains to be seen whether they were correct.

Christa Scholtz, PhD

Department of Political Science

McGill University

christa.scholtz@mcgill.ca

Maryna Polataiko, B.A., B.C.L./LL.B.

101 British Columbia, Canada, and Nisga'a Nation, Nisga'a Final Agreement, (Ottawa: Federal Treaty Negotiation Office, 1999), section 2.8(a). Parliament gave the Nisga'a Final Agreement force of law under the Nisga'a Final Agreement Act, SC 2000, c 7.

102 Sgánism Simaugit (Chief Mountain) v Canada (Attorney General), 2013 BCCA 49 at para 72.

103 Ibid., paras 95-97.

104 Wade K. Wright, "Courts as Facilitators of Intergovernmental Dialogue: Cooperative Federalism and Judicial Review," Supreme Court Law Review (2d) 72 (2006): 365. For the court's interest in upholding intergovernmental agreements despite division-of-powers difficulties, see generally the work of Johanne Poirier. For instance, Johanne Poirier, "Souveraineté parlementaire et armes à feu : le fédéralisme coopératif dans la ligne de mire?" Revue de Droit de l'Université de Sherbrooke 45, no. 1-2 (2015): 47.

105 See Reference re Secession of Québec, [1998] 2 SCR 217; also Reference re Senate Reform, [2014] 1 SCR 704. 